\title{
Sistem Informasi Prediksi Penilaian Kredit Perbankan Menggunakan Algoritma K-Nearest Neighbor Classification
}

\author{
I Wayan Supriana ${ }^{1}$, Made Agung Raharja ${ }^{2}$, Putu Wida Gunawan ${ }^{3}$ \\ ${ }^{1,2,3}$ Program Studi Teknik Informatika, Universitas Dhyana Pura \\ Universitas Dhyana Pura \\ Mangupura, Indonesia \\ Email: supriana@undhirabali.ac.id ${ }^{1}$, agungraharja@undhirabali.ac.id ${ }^{2}$, \\ putu.wida@gmail.com ${ }^{2}$
}

\begin{abstract}
ABSTRAK
Keberadaan lembaga perbankan sangat penting bagi kehidupan masyarakat, terutama digunakan untuk menghimpun dana baik dalam bentuk deposito, giro, tabungan dan lainnya. Disamping hal itu lembaga perbankan juga dapat berperan sebagai penyalur bantuan dana dalam bentuk kredit kepada masyarakat dan badan usaha yang memerlukan. Permasalahan dalam penyeluran kredit menyebabkan kredit macet dari nasabah sehingga menyebabkan kerugian pada bank tersebut. Penilaian kredit merupakan salah satu tahapan penting yang harus dilakukan oleh pihak bank sebelum kredit diberikan kepada pemohon kredit. Proses penilaian kredit tergolong kedalam permasalahan semi terstruktur yang cukup kompleks, oleh sebab itu dibutuhkan pengembangan sistem untuk memprediksi kelayakan terhadap pengajuan kredit. Sistem yang dibangung dalam penelitian ini menggunakan algoritma KNearest Neighbor Classification dengan menilai calon debitur dari data training yang digunakan. Berdasarkan penelitian yang sudah dilakukan, algoritma K-Nearest Neighbor Classification dapat dimodelkan dalam penilaian kredit perbankan. Nilai $\mathrm{k}$ yang digunakan adalah $3,5,7$ dan 9 , Hasil pengujian sistem menunjukkan akurasi terbaik yaitu $81,82 \%$ dengan nilai $\mathrm{K}=5, \mathrm{~K}=7$ dan $\mathrm{K}=9$.
\end{abstract}

Kata kunci: Perbankan, Kredit, Debitur, K-Nearest Neighbor Classification

\begin{abstract}
The existence of banking institutions is very important for the community, mainly used to raise funds in the form of deposits, demand deposits, savings and others. Besides this, banking institutions can help channel funds in the form of loans to the public and business entities that request them. The problem with saving credit caused bad credit because it caused losses to the bank. Credit assessment is one of the important steps that must be carried out by the bank before credit is given to credit applicants. The process of considering credit is classified as semi-structured which is quite complex, therefore it is necessary to develop a system to predict the feasibility of credit applications. The system built in this study uses the K-Nearest Neighbor Classification algorithm with the acquisition of prospective debtors from the training data used. Based on the research that has been done, the KNearest Neighbor Classification algorithm can be modeled in the Banking Credit Agreement. The $k$ values used are 3, 5, 7 and 9, the system test results prove the best test is $81.82 \%$ with $K=5, K=7$ and $K=9$
\end{abstract}

Keywords: Banking, Credit, Debtor, K-Nearest Neighbor Classification

\section{PENDAHULUAN}

Perbankan adalah lembaga keuangan yang bertindak sebagai penopang perekonomian masyarakat kelas bawah sampai kelas atas (Aryawan, 2008). Keberadaan lembaga keuangan ini sangat penting bagi kehidupan masyarakat yaitu dalam menghimpun dana masyarakat baik dalam bentuk deposito, giro, tabungan dan lainnya. Disamping itu lembaga perbankan juga berperan dalam menyalurkan bantuan dana dalam bentuk kredit kepada 
masyarakat dan badan usaha yang memerlukan pendanaan.

Meningkatnya daya saing dalam dunia perbankan saat ini mendorong pihak bank menerapkan berbagai solusi dalam menyelesaikan permasalahan yang menghambat proses atau prosedur pendanaan yang disalurkan kepada masyarakat. Penyaluran kredit adalah salah satu permasalahan yang dihadapi lembaga perbankan saat ini karena banyak indikator atau kriteria yang harus dipertimbangkan sebelum pendanaan tersebut disalurkan.

Permasalahan dalam penyeluran kredit sehingga menyebabkan kredit macet dari nasabah akan menyebabkan kerugian pada bank, hal ini karena pendapatan terbesar dari bank berasal dari bunga kredit. kegiatan simpan pinjam merupakan kegiatan utama dari perbankan. Apabila memperhatikan neraca bank, akan terlihat bahwa sisi aktiva bank didominasi oleh besarnya jumlah kredit. Demikian juga bila diamati sisi pendapatan bank, akan diketahui bahwa pendapatan terbesar bank adalah dari pendapatan bunga dan provisi kredit.

Proses penyaluran kredit oleh suatu bank dilakukan melalui beberapa tahapan sampai akhirnya diputuskan apakah kredit yang dimohon oleh calon debitur kepada pihak bank (kreditur) layak diberikan atau tidak. secara umum tahapan dalam pemberian kredit adalah sebagai berikut:

1) Pengumpulan informasi tentang calon dibitur

2) Penilaian/analisis proposal kredit

3) Keputusan kredit

4) Pelaksanaan/pencairan kredit

Prosedur penentuan pemberian kredit memerlukan waktu yang cukup lama terutama pada tahapan analisis proposal kredit. Hal ini karena analisis proposal kredit merupakan tahapan terpenting dalam proses pemberian kredit oleh perbankan. Indikator atau kriteria yang dipertimbangkan pada tahap ini bukan saja bersifat kuantitatif tapi cenderung bersifat kualitatif yang banyak melibatkan unsur subyektivitas daripada obyektivitas. Permasalahan dalam melakukan analisis akan berakibat munculnya kredit bermasalah di kemudian hari.

Jumlah debitur yang semakin meningkat dari waktu ke waktu tentunya akan menyulitkan pihak kreditur dalam manajemen kreditnya. Berkas transaksi akan semakin menumpuk jika pengerjaannya belum sepenuhnya menggunakan komputer. Kualitas informasi (revelancy, accuracy, timeliness, usabality, offordability, adaptability, accessibility) yang dihasilkan juga tidak akan maksimal. Oleh karena itu, diperlukan suatu sistem yang benar-benar dapat membantu dan menghemat waktu dalam tahap analisis ini.

Proses penilaian kelayakan kredit merupakan permasalahan semi terstruktur yang cukup rumit karena ada banyak faktor penilaian, oleh sebab itu dibutuhkan sebuah sistem untuk memprediksi kelayakan terhadap pengajuan kredit oleh calon debitur. Analisis penentuan indikator atau kriteria pengajuan kredit memiliki kesamaan terhadap data-data debitur berdasarkan kedekatan data lama dengan data baru (Leidiyana, 2004). Dalam penelitian ini akan menerapkan penggunaan sistem informasi berbasis komputer dan model yang digunakan untuk menganalisis calon debitur adalah algoritma k-nearest neighbor. Dasar algoritma digunakan sebagai model klasifikasi dalam penelitian ini adalah proses pelatihan data sangat cepat, sederhana dan mudah dipelajari, tahan lama terhadap data pelatihan yang memiliki derau serta efektif jika data pelatihan besar (Mutrofin dkk, 2014).

Algoritma K-Nearest Neighbor (K-NN) adalah sebuah metode klasifikasi terhadap sekumpulan data berdasarkan pembelajaran data yang sudah terklasifikasikan sebelumya. Algoritma ini juga merupakan salah satu teknik lazy learning. K-NN dilakukan dengan mencari kelompok k objek dalam data training yang paling dekat (mirip) dengan objek pada data baru atau data testing (Jayanti, 2014). Tahapan Langkah Algoritma K-NN adalah sebagai berikut

1) Menentukan parameter k (jumlah tetangga paling dekat) maksimum sebesar $25 \%$ dari data latih

2) Menghitung kuadrat jarak eucliden objek terhadap data training yang diberikan

3) Mengurutkan hasil no 2 secara ascending (berurutan dari nilai tinggi ke rendah)

4) Mengumpulkan kategori $Y$ (Klasifikasi nearest neighbor berdasarkan nilai $k$ )

5) Menggunakan kategori nearest neighbor yang paling mayoritas maka dapat dipredisikan kategori objek

Secara umum untuk mendefinisikan jarak antara dua objek $x$ dan $y$, digunakan 
rumus jarak Euclidean adalah sebagai berikut:

$$
\begin{array}{ll} 
& \multicolumn{1}{c}{d_{x y}=\sqrt{\sum_{i=1}^{n}\left(x_{i}-y_{i}\right)^{2}}} \\
d_{x y} & \text { : Jarak Euclidean } \\
x & \text { : Data latih } \\
y & \text { : Data uji } \\
i & \text { : Fitur ke- } \\
n & \text { : Jumlah fitu }
\end{array}
$$

Pada penelitian ini proses penilaian kredit diharapkan lebih tepat dan akurat sehingga penyaluran kredit yang dilakukan tidak menjadi masalah dikemudian hari.

\section{METODE}

Pengembangan sistem dalam penelitian ini menggunakan model System Development Life Cycle (SDLC)

\section{A. Analisis}

Proses penilaian kredit perbankan merupakan hal yang tidak mudah dan harus memperhatikan berbagai aspek dari proses identifikasi yang sifatnya valid. Prinsip-prinsip penilaian kredit dalam penelitian ini menggunakan analisis $5 \mathrm{C}$ yaitu:

1) Character: sifat atau watak seseorang calon debitur

2) Capacity: kemampuan calon debitur dalam membayar kredit

3) Capital: mengetahui sumber pembiayaan lain dari calon debitur terhadap usaha yang akan dibiayai oleh bank

4) Callateral: jaminan yang diberikan calon debitur baik yang bersifat fisik maupun non fisik

5) Condition: menilai calon debitur dari kondisi ekonomi sekarang dan untuk di masa yang akan datang sesuai sektor masing-masing.

Luaran dari proses penilaian ini dapat dimanfaatkan sebagai dasar dalam penerimaan kelayakan proposal kredit bagi nasabah. Kendala yang ditemukan dalam proses penilaian kelayakan proposal kredit adalah sebagai berikut:

1) Waktu yang diperlukan untuk melakukan proses penilaian kelayakan proposal kredit cukup lama karena belum adanya sistem komputer yang mendukung penilaian

2) Sulitnya menentukan kelayakan proposal kredit karena penentuan kelayakan menggunakan kriteria kuantitatif dan syarat-syarat adminitrasi

3) Berkas-berkas analisis kredit yang cukup banyak

4) Hasil analisis yang kadangkala mengecewakan debitur

Berdasarkan hasil analisis terhadap permasalahan proses penilaian kredit perbankan, maka dibutuhkan informasi sebagi berikut:

1) Informasi tentang debitur pemohon kredit

2) Informasi tentang prosedur pemberian kredit

3) Informasi tentang hasil penilaian berdasarkan kriteria-kriteria yang diinginkan oleh pihak bank dalam hal ini penganalisis kredit

4) Informasi tentang layak atau tidak layaknya seorang calon debitur mendapatkan kredit

5) Laporan hasil penilaian kelayakan proposal kredit

Berdasarkan informasi sistem maka dapat diuraikan analisis kebutuhan fungsional yang digambarkan dalam diagram use case yang menjelaskan hubungan antara aktor sebagai pengguna dengan sistem yang dibangun. Diagram use case disajikan pada gambar 1 .

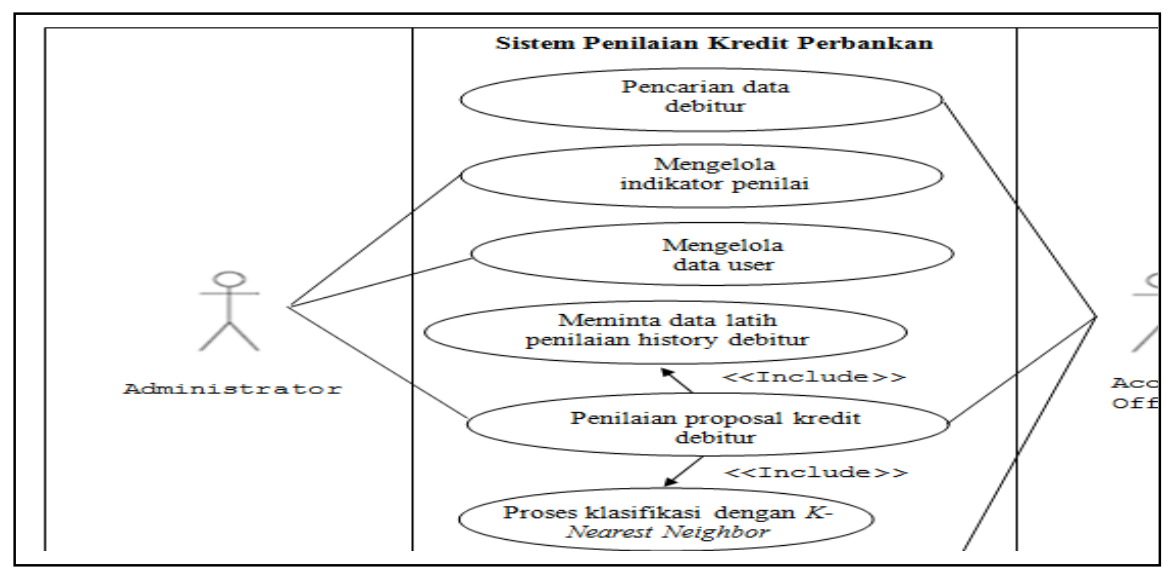

Gambar 1. Diagram Use Case Sistem Penilaian Kredit Perbankan 
Selanjutnya menentukan kebutuhan non-fungsional sistem yang merupakan kebutuhan untuk mendapatkan umpan balik yang resposnsif dari pengguna sistem (Menarianti, 2015) antara lain:

- Performa: sistem dapat melaksakan perintah-perintah secara menyeluruh dalam waktu yang singkat berdasarkan input data yang diberikan.

- Informasi: sistem dapat memberikan informasi mengenai data dalam sistem

- Ekonomi: sistem mampu beroperasi secara optimal tanpa memerlukan biaya yang tinggi

- Kontrol: sistem yang sudah jalan tetap dilakukan pengawasan sehingga sistem selalu bekerja secara optimal dan hasil yang dikeluarkan memenuhi kebutuhan pengguna.

- Efisiensi: sistem yang dibangun dirancang secara sederhana sehingga pengguna mampu memahami pada saat menggunakannya.

- Pelayanan: sistem yang dibangun dapat dikembangkan ke tingkat yang lebih kompleks untuk pengembangan berikutnya.

Tingkat akurasi sistem yang dibangun diukur berdasarkan sekenario pengujian menggunakan persamaan sebagai berikut:

$$
\text { Akurasi }=\frac{\sum \text { data uji benar }}{\sum \text { data uji }} \times 100 \%
$$

\section{B. Perancangan}

Tahap berikutnya merupakan perancangan setelah langkah analisis selesai dilakukan. Tahapan penilaian proposal kredit menggunakan metode K-Nearest Neighbor, pada model ini proses klasifikasi kredit berdasarkan indikator 5C yang digunakan.
Proses penilaian klasifikasi ditentukan berdasarkan $\mathrm{K}$ tetangga terdekat antara data uji dengan data latih sistem. Proses klasifikasi dilakukan melalui dua tahapan:

- Preprocessing data merupakan proses awal yang bertujuan untuk mempersiapkan history data debitur yang akan mengalami pengolahan pada proses selanjutnya. Pada tahap ini data disiapkan untuk menjadi data latih sistem yaitu mengidentifikasi dengan mentransformasi data ke suatu format yang prosesnya lebih mudah dan efisien. Selain itu pada tahap ini juga dilakukan penghapusan data berupa: gangguan (noisy), data tidak konsisten (inconsisten) dan data tidak lengkap (incomplate). Jumlah data latih sebanyak 40 data berdasarkan data primer di lapangan terdapat 40 data nasabah terklasifikasi melalui prinsip-prinsip 5C pada tahun 2018. Sementara data uji sebanyak 11 data uji dari sebaran data nasabah di daerah tabanan. Sehingga jumlah data latih dan data uji sebanyak 55 data set.

- Klasifikasi data merupakan tahap klasifikasi data pengajuan proposal kredit dengan model K-Nearest Neighbor, algoritma ini melakukan klasifikasi proposal kredit berdasarkan pembelajaran data history proposal kredit atau yang sudah terklasifikasi sebelumnya atau data training (Mustakin, 2016). Proses pembelajaran dilakukan berdasarkan hasil query instance yang baru diklasifikasi berdasarkan mayoritas kedekatan jarak dari katagori yang ada di K-Nearest Nieghbor (Nugraha, 2017).

Flowchart proses klasifikasi kelayakan proposal kredit digambarkan pada gambar 2 .

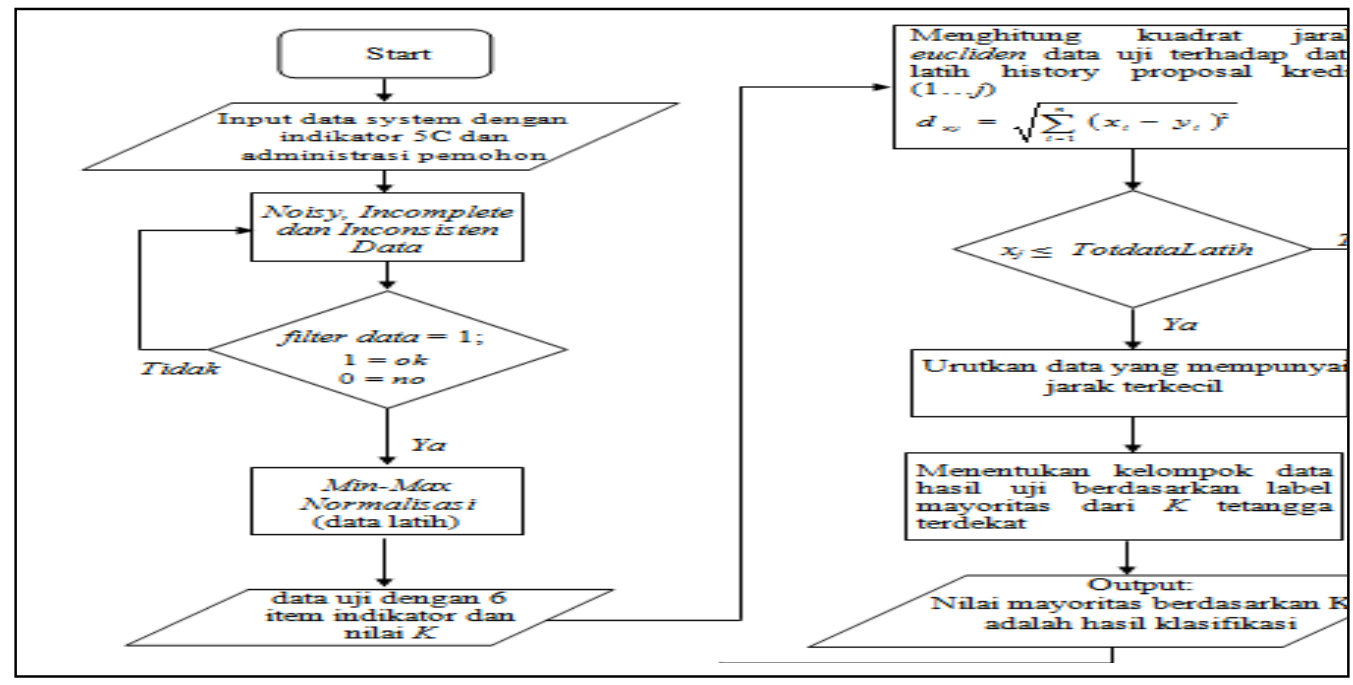

Gambar 2. Metode K-Nearest Neighbor Classification 
Flowcahart pada gambar 2 menguraikan mengenai proses pada penilaian kredit dengan menggunakan algoritma K-Nearest Neighbor, secara rinci dapat diuraikan sebagai berikut:

1. Baca data inputan

2. Proses preprosesing data input

a. lakukan pembersihan data dari noisy, incomplete dan inconsisten

b. normalisasi proses pembersihan dengan nim-max normalisation

3. Proses klasifikasi

a. hitung jarang data uji terhadap semua data latih sistem b. mengurutkan jarak data uji dengan data latih dari yang terkecil sampai terbesar dengan jumlah $K$ tetangga terdekat (25\% dari data latih)

4. Hasil klasifikasi adalah data mayoritas dengan $\mathrm{K}$ tetangga terdekat

\section{Selesai}

Analisis kebutuhan pengguna sistem menunjukkan proses yang akan terjadi pada sistem yang dikembangkan melalui desain sistem berupa Data Flow Diagram (DFD) yang disajikan pada gambar 3 .

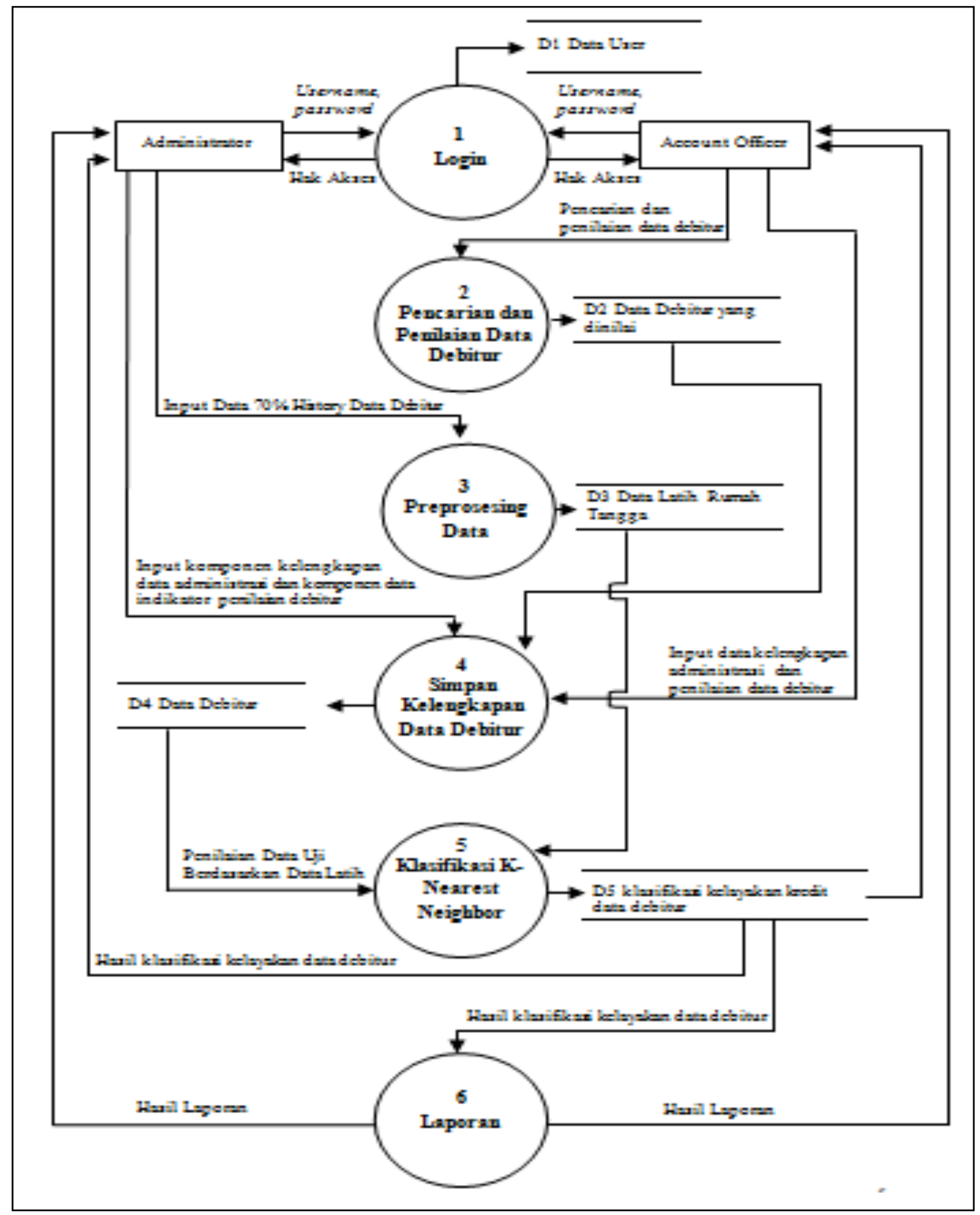

Gambar 3. Data Flow Diagram Level 1 
Proses pertama adalah proses login untuk level user administrator yang memiliki kewenangan sebagai user untuk proses input komponen kelengkapan data administrasi, data indikator penilaian, data latih penilaian dan data user. Level berikutnya adalah pengguna sistem yaitu account officer yang memiliki fungsionalitas mencari data debitur lama dengan menambahkan penilaian data debitur serta menginputkan data debitur baru dengan menginputkan data kelengkapan administrasi dan penilaian data debitur. Proses selanjutnya adalah penilaian data debitur dengan metode K-Nearest Neighbor. Proses terakhir adalah pelaporan proses penilaian dengan menentukan layak atau tidaknya proposal kredit yang diajukan berdasarkan indikator sistem.

Selanjutnya desain Entity relationship diagram (ERD) pada sistem informasi penilaian kredit perbankan menggunakan algoritma K-Nearest Neighbor classification, terdapat 6 entitas yang terlibat dalam relasi yaitu user, debitur, indikator, detail indikator, data latih dan kelayakan kredit.

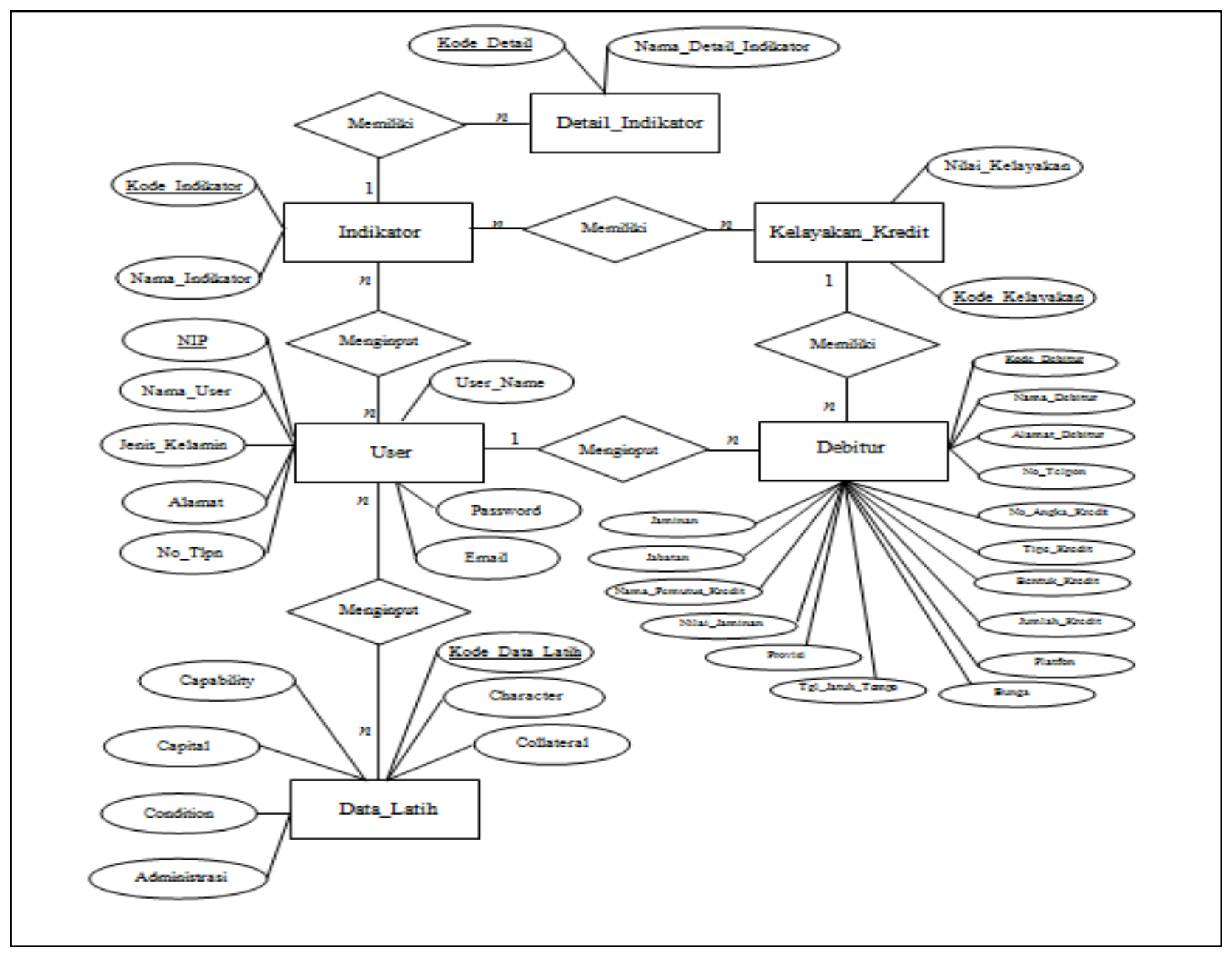

Gambar 4. Entity Relationship Diagram

\section{HASIL DAN PEMBAHASAN}

Hasil penelitian dari analisis dan desain yang sudah dilakukan akan di uraikan sebagai berikut

\section{A. Hasil Tahap Analisis}

Proses predisksi penilaian kredit dilakukan melalui identifikasi kelengkapan administrasi dan selanjutnya penilaian dengan analisis 5C. Adapun penilaian calon debitur dilakukan pada bank BPD cabang Kediri Tabanan, berikut data salah satu calon debitur yang dinilai. Kode_Debitur = 20180309001, Nama $=\mathrm{Ni}$ Nyoman Suci Anggreni, Alamat $=$ Kediri Kaba-Kaba, No_Tlp $=081273122232$, No_Angka_Kredit $=$ ak021, Tipe_Kredit = konsumtif, Bentuk_Kredit $=$ pembelian kendaraan bermotor, Jumlah_Kredit $=20.000 .000$, platfon $=15.000 .000$, Bunga $=11,65 \%$ pertahun, Tgl_Jatuh_Tempo $=3$ september 2023 , provisi $=5 \%$ dari pinjaman, Jaminan $=$ bpkb kendaraan roda dua, Nilai_Jaminan $=$ 20.000.000, Nama_Pemutus_Kredit $=$ Indah 
Pradnya, Jabatan = Manajer Pemasaran. Berdasarkan analisis kelengkapan adminitrasi memiliki nilai sedang.

Proses penilaian selanjutnya adalah $5 \mathrm{C}$ dengan analisis yang sudah dilakukan maka calon debitur diatas dengan nilai: character $=$ bagus, capability = bagus, capital = buruk, collateral $=$ bagus, condition $=$ bagus. Proses klasifikasi dengan metode K-Nearest Neighbor maka jarak data uji dengan data latih diperoleh seperti tabel 1.

Tabel 1. Jarak Data Pengujian dengan Data Latih

\begin{tabular}{|c|c|c|c|c|c|}
\hline $\begin{array}{l}\text { Data } \\
\text { Latih }\end{array}$ & Jarak & Kelayakan Kredit & $\begin{array}{l}\text { Data } \\
\text { Latih }\end{array}$ & Jarak & Kelayakan Kredit \\
\hline 1 & 1.22 & Tidak Layak & 21 & 1.41 & Tidak Layak \\
\hline 2 & 1.00 & Tidak Layak & 22 & 1.32 & Tidak Layak \\
\hline 3 & 1.58 & Layak & 23 & 1.22 & Layak \\
\hline 4 & 1.41 & Layak & 24 & 0.71 & Layak \\
\hline 5 & 1.87 & Tidak Layak & 25 & 1.22 & Tidak Layak \\
\hline 6 & 1.66 & Tidak Layak & 26 & 1.22 & Layak \\
\hline 7 & 1.41 & Tidak Layak & 27 & 1.12 & Layak \\
\hline 8 & 1.22 & Tidak Layak & 28 & 0.50 & layak \\
\hline 9 & 1.12 & Layak & 29 & 1.32 & Layak \\
\hline 10 & 1.32 & Tidak Layak & 30 & 1.32 & Tidak Layak \\
\hline 11 & 1.41 & Layak & 31 & 1.12 & Layak \\
\hline 12 & 1.41 & layak & 32 & 1.87 & Tidak Layak \\
\hline 13 & 1.22 & layak & 33 & 1.12 & Layak \\
\hline 14 & 1.00 & Tidak Layak & 34 & 1.41 & Layak \\
\hline 15 & 1.22 & Layak & 35 & 1.58 & Tidak Layak \\
\hline 16 & 1.58 & Tidak Layak & 36 & 0.71 & Layak \\
\hline 17 & 1.32 & Layak & 37 & 1.00 & Layak \\
\hline 18 & 1.12 & layak & 38 & 1.50 & Tidak Layak \\
\hline 19 & 1.66 & Tidak Layak & 39 & 0.00 & Layak \\
\hline 20 & 1.12 & Layak & 40 & 1.32 & Tidak Layak \\
\hline
\end{tabular}

Sebagai contoh nilai $\mathrm{K}$ yang digunakan pada kasus diatas adalah 9 Sehingga jarak di urutkan dari jarak terkecil sebanyak 9 data, kemudian data ini akan ditentukan mayoritas data untuk menentukan klasifikasi.

Tabel 2. Pengurutan Data Uji

\begin{tabular}{|c|c|c|}
\hline Data Latih & Jarak & Kelayakan Kredit \\
\hline 39 & 0.00 & Layak \\
\hline 28 & 0.50 & layak \\
\hline 24 & 0.71 & Layak \\
\hline 36 & 0.71 & Layak \\
\hline 2 & 1.00 & Tidak Layak \\
\hline 14 & 1.00 & Tidak Layak \\
\hline 37 & 1.00 & Layak \\
\hline 9 & 1.12 & Layak \\
\hline 18 & 1.12 & layak \\
\hline
\end{tabular}


Berdasarkan pengurutan data uji maka penilaian kredit atas nama calon debitur $\mathrm{Ni}$ Nyoman Suci Anggreni dengan alamat Kediri

Kaba-Kaba dengan mayoritas kelayakan kredit dengan label layak maka dapat disimpulkan kredit yang diajukan layak diterima proposal kreditnya.

\section{B. Hasil Tahap Analisis}

Perhitungan manual pada hasil tahap analisis jika dibangingkan penilaian melalui sistem maka setiap proses pada sistem dapat disajikan pada gambar 5 .

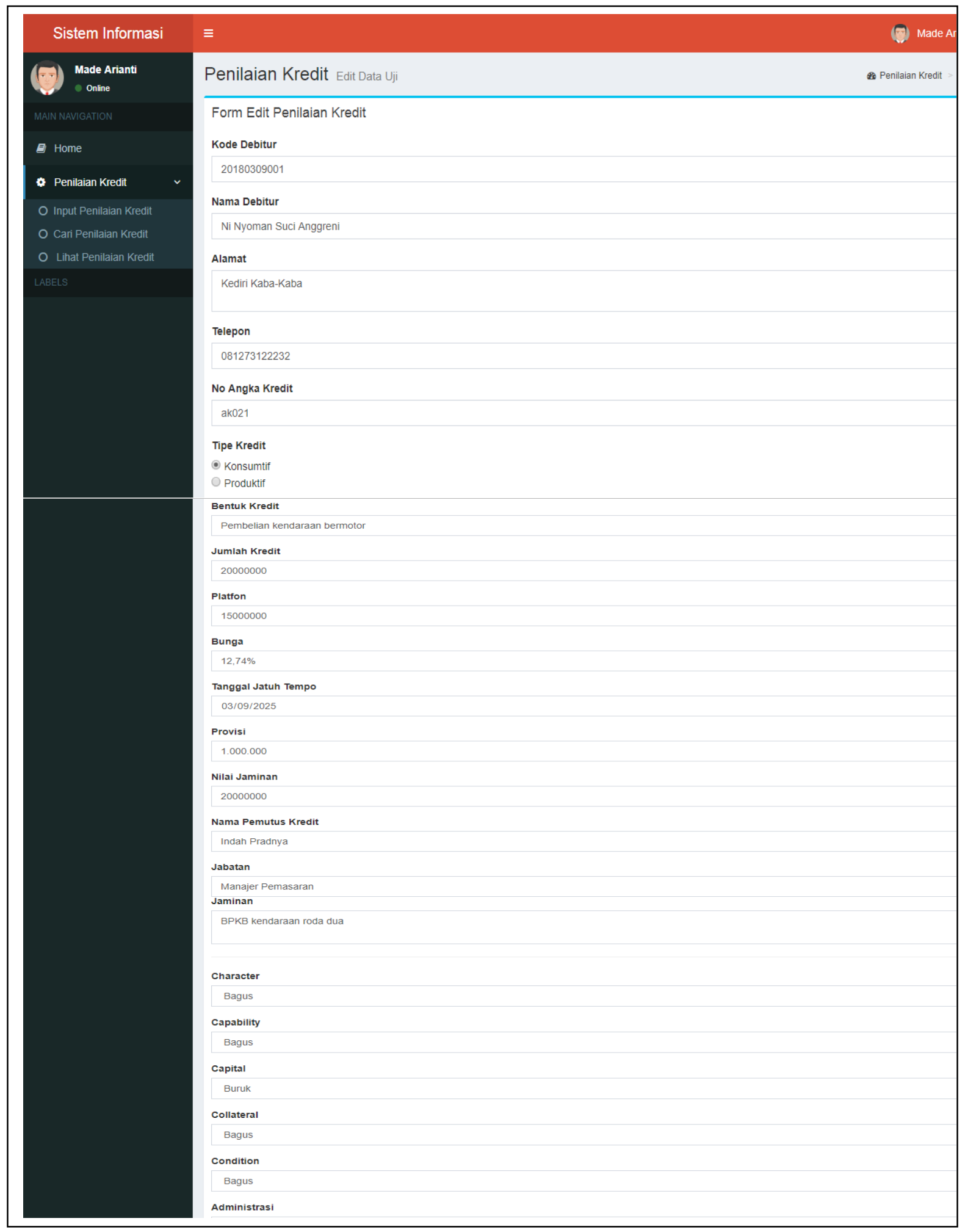

Gambar 5. Proses Penilaian Data Administrasi dan 5C 


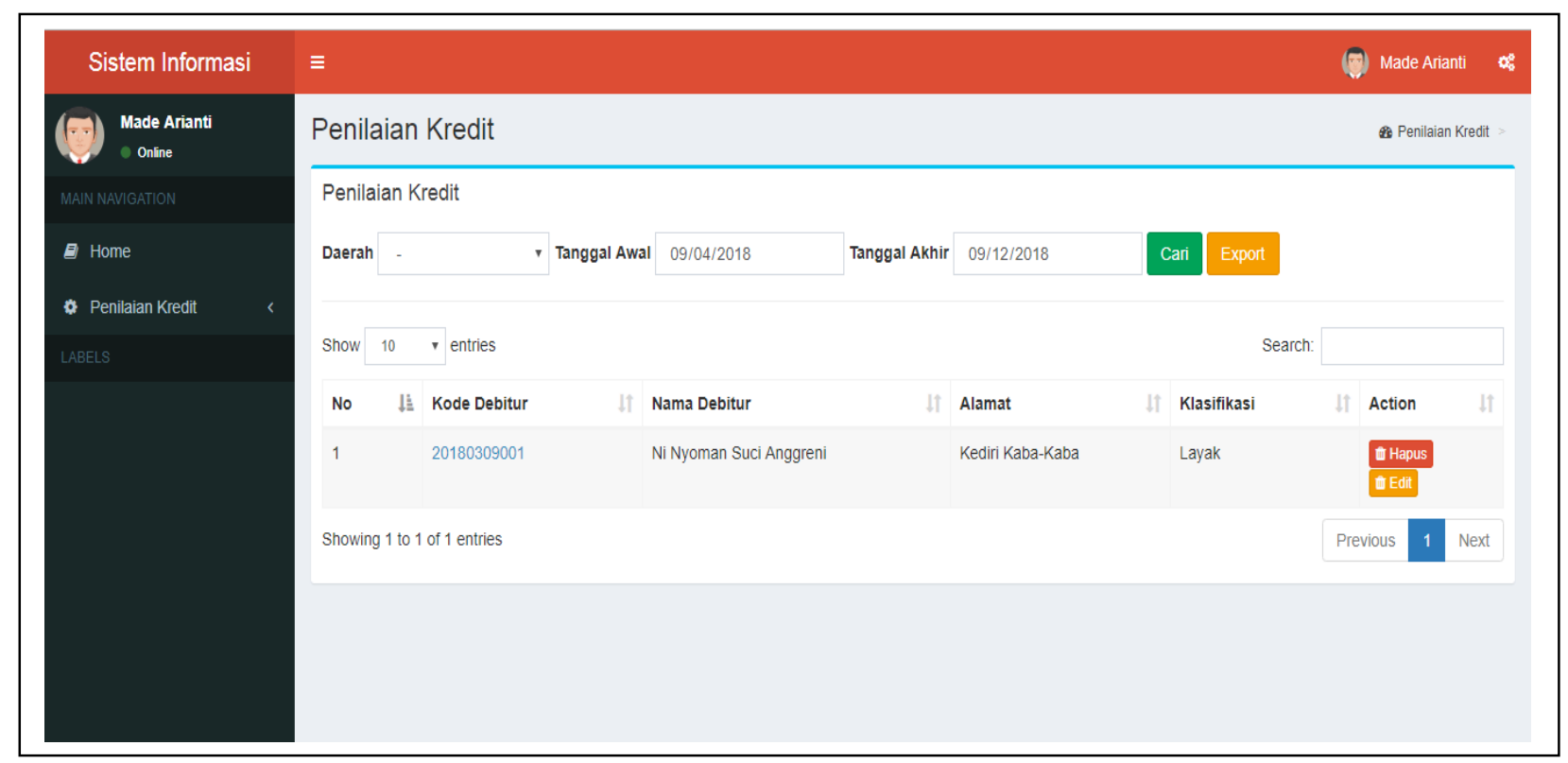

Gambar 6. Hasil Penilaian Kelayakan Kredit

Melalui proses penilaian dengan sistem, klasifikasi yang dihasilkan berada pada tingkat yang sama dengan proses manual yaitu layak diterima proposal kreditnya. Selanjutnya akan dilakukan pengujian terhadap 10 calon dibitur berdasarkan perhitungan sistem. Nilai $\mathrm{K}$ yang digunakan adalah $3,5,7$ dan 9 , nilai ini ditentukan lebih besar dari satu, bernilai ganjil untuk menghindari jumlah kelas bernilai sama serta maksimum sebesar $25 \%$ dari sebaran data latih. Pada uraian dibawah ini hasil yang disajikan berdasarkan nilai $\mathrm{K}=9$

1) Calon debitur Ni Nyoman Mudereni asal dari Wanasari, dengan hasil sepuluh rangking terbaik yaitu layak sebanyak 5 item dan tidak layak sebanyak 4 item. Sehingga pada proses penilaian dengan sistem dapat dinyatakan calon debitur ini tidak layak diterima pengajuan kreditnya.

2) Calon debitur I Made Arta Berana asal dari Tunjuk, dengan hasil sepuluh rangking terbaik yaitu layak sebanyak 6 item dan tidak layak sebanyak 3 item. Sehingga pada proses penilaian dengan sistem dapat dinyatakan calon debitur ini layak diterima pengajuan kreditnya.

3) Calon debitur I Nyoman Budiastra asal dari Tunjuk, dengan hasil sepuluh rangking terbaik yaitu layak sebanyak 9 item dan tidak layak sebanyak 0 item. Sehingga pada proses penilaian dengan sistem dapat dinyatakan calon debitur ini layak diterima pengajuan kreditnya.
4) Calon debitur I Wayan Narki asal dari Penebel, dengan hasil sepuluh rangking terbaik yaitu layak sebanyak 9 item dan tidak layak sebanyak 0 item. Sehingga pada proses penilaian dengan sistem dapat dinyatakan calon debitur ini layak diterima pengajuan kreditnya.

5) Calon debitur Ni Wayan Nandra asal dari Sudimara, dengan hasil sepuluh rangking terbaik yaitu layak sebanyak 5 item dan tidak layak sebanyak 4 item. Sehingga pada proses penilaian dengan sistem dapat dinyatakan calon debitur ini layak diterima pengajuan kreditnya.

6) Calon debitur I Ketut Mertadana asal dari Penebel, dengan hasil sepuluh rangking terbaik yaitu layak sebanyak 9 item dan tidak layak sebanyak 0 item. Sehingga pada proses penilaian dengan sistem dapat dinyatakan calon debitur ini layak diterima pengajuan kreditnya.

7) Calon debitur I Made Sukarwa asal dari Selemadeg, dengan hasil sepuluh rangking terbaik yaitu layak sebanyak 3 item dan tidak layak sebanyak 6 item. Sehingga pada proses penilaian dengan sistem dapat dinyatakan calon debitur ini tidak layak diterima pengajuan kreditnya.

8) Calon debitur I Wayan Rameg asal dari Beraban, dengan hasil sepuluh rangking terbaik yaitu layak sebanyak 9 item dan tidak layak sebanyak 0 item. Sehingga pada proses penilaian dengan sistem dapat dinyatakan calon debitur ini layak diterima pengajuan kreditnya. 
9) Calon debitur Ni Wayan Suryani asal dari Grogak, dengan hasil sepuluh rangking terbaik yaitu layak sebanyak 9 item dan tidak layak sebanyak 0 item. Sehingga pada proses penilaian dengan sistem dapat dinyatakan calon debitur ini layak diterima pengajuan kreditnya.

10) Calon debitur Yuni Nurhayati asal dari Grogak, dengan hasil sepuluh rangking terbaik yaitu layak sebanyak 6 item dan tidak layak sebanyak 3 item. Sehingga pada proses penilaian dengan sistem dapat dinyatakan calon debitur ini layak diterima pengajuan kreditnya.

Sementara untuk penilaian manual yang sudah dilakukan oleh bank BPD cabang Kediri menghasilkan data disajikan pada tabel 3.

Tabel 3. Data Penilaian Debitur Bank BPD Kediri Tabanan Bulan Januari Tahun 2018

\begin{tabular}{|c|l|l|c|}
\hline No & \multicolumn{1}{|c|}{ Nama Debitur } & \multicolumn{1}{c|}{ Alamat } & Kelayakan Penilaian Kredit \\
\hline 1 & Ni Nyoman Suci Anggraeni & Sesandan & Layak \\
\hline 2 & Ni Nyoman Mudereni & Wanasari & Tidak Layak \\
\hline 3 & I Made Arta Berana & Tunjuk & Layak \\
\hline 4 & I Nyoman Budiastra & Tunjuk & Tidak Layak \\
\hline 5 & I Wayan Narki & Penebel & Layak \\
\hline 6 & Ni Wayan Nandra & Sudimara & Layak \\
\hline 7 & I Ketut Mertadana & Penebel & Tidak Layak \\
\hline 8 & I Made Sukarwa & Selemadeg & Layak \\
\hline 9 & I Wayan Rameg & Beraban & Layak \\
\hline 10 & Ni Wayan Suryani & Grogak & Tidak Layak \\
\hline 11 & Yuni Nurhayati & Grogak & \\
\hline
\end{tabular}

Hasil pengujian sistem jika disandingkan dengan data penilaian pihak bank BPD cabang Kediri Tabanan dengan data yang sama dengan data uji sistem, bahwa penilaian mendekati proses penilaian manual. Pada pengujian 11 data di identifikasi dan di klasifikasi oleh sistem dengan 1 perbedaan klasifikasi jika dibandingkan dengan proses penilaian manual dari data analisis pihak bank BPD cabang Kediri Tabanan. Demikian juga untuk nilai $\mathrm{K}=5, \mathrm{~K}=7$ hasil yang diperoleh dari sistem sama dengan pengujian dengan $K=9$, sehingga akurasi yang dihasilkan oleh sistem dapat dihitung sebagai berikut.

Persentase Akurasi $=\frac{9}{11} \times 100 \%=81,82 \%$

Hasil akurasi dari pengujian sistem dengan $\mathrm{K}=5, \mathrm{~K}=7$ dan $\mathrm{K}=9$ diperoleh sebesar $81,82 \%$ sistem mampu mengidentifikasi calon debitur Bank BPD, dengan tingkat kesalahan sebesar $18,18 \%$ melalui data latih sebanyak 40 data dan 11 data uji. Sementara untuk nilai $\mathrm{K}=3$ nilai perhintungan dengan sistem menghasilkan akurasi sebesar $72,22 \%$.

\section{SIMPULAN}

Berdasarkan uraian penelitian, maka kesimpulan yang dihasilkan sebagai berikut:

- Analsis dan pemodelan sistem prediksi penilaian kredit perbankan dapat dilakukan pengembangan aplikasinya berdasarkan faktor penilaian dari bank

- Metode K-Nearest Neighbor dapat diterapkan dan mampu mengklasifikasi penilaian kredit debitur untuk menentukan layak atau tidaknya sebuah proposal kredit dengan tingkat akurasi sebesar $81,82 \%$ untuk $\mathrm{K}=5, \mathrm{~K}=7$ dan $\mathrm{K}=9$.

\section{UCAPAN TERIMAKASIH}

Ucapan terimakasih kepada UNDHIRA (Universitas Dhyana Pura) melalui Lembaga Penelitian dan Pengabdian Kepada Masyarakat dan Fakultas IImu Keshatan, Sains dan Teknologi Universitas Dhyana Pura yang telah membiayai pelaksanaan penelitian ini, serta bank BPD cabang Kediri Tabanan.

\section{DAFTAR PUSTAKA}

Aryawan, I Wayan, 2008, Rancangan Sistem Pendukung Keputusan Penilaian Kelayakan Proposal Kredit, Skripis, Universitas Udayana.

Jayanti, R.D. "Aplikasi Metode K-Nearest Neighbor Dan Analisa Diskriminan Untuk Analisa Resiko Kredit Pada Koperasi Simpan Pinjam Di Kopinkra Sumber Rejeki". Prosiding Seminar Nasional Aplikasi Sains dan Teknologi (SNAST). Yogyakarta. 2014. 
Leidiyana. "Penerapan Algoritma K-Nearest Neighbor Untuk Penentuan Resiko Kredit Kepemilikan Kendaraan Bemotor". Jurnal Penelitian IImu Komputer, System Embedded \& Logic, Vol : 1. STMIK Nusa Mandiri. 2010.

Menarianti, I. 2015. "Klasifikasi Data Mining Dalam Menentukan Pemberian Kredit Bagi Nasabah Koperasi” Jurnal IImiah Teknosains, Vol.1, No1, 2015

Mustakin. Oktaviani, G. 2016. "Algoritma KNearest Neighbor Classification Sebagai Sistem Prediksi Predikat Prestasi Mahasiswa". Jurnal Sains, Teknologi dan Industri, Vol.13, No.2 2016.

Mutrofin, S. Izzah, A. Kurniawardhani, A. Masrur, M. 2014. " Optimasi Klasifikasi Modified $K$ Nearest Neighbor Menggunakan Algoritma Genetika" Jurnal Gamma, Vol. 10, No. 1, 2014.

Nugraha, D.W, Putri, R.R.M dan Wihandika, R.C, 2017. "Penerapan Fuzzy KNearest Neighbor (FK-NN) Dalam Menentukan Status Gizi Balita". Jurnal Pengembangan Teknologi Informasi dan IImu Komputer, Vol.1, No.9, 2017 